\title{
Yom Kippur War Influence at the PLO Recognition and the Palestinian Problem
}

\author{
Shaul Bartal \\ Bar-Ilan University
}

\begin{abstract}
On November 1973, about one month after the cease-fire at the end of the Yom Kippur War, the Arab League decided that the Palestine Liberation Organization (PLO) was the sole representative of the Palestinian people. This article examines the contribution of the PLO to the war effort of the Arab countries during the Yom Kippur War, the influence of the war upon the Palestinian problem, the Palestinian military contribution to the Arab war effort, Jordan's non-participation in the Yom Kippur War and the Egyptian attempt to include the PLO as the representative of the Palestinian people in future negotiations with Israel and the U.S. which enabled the PLO recognition as the Palestinians sole representative for 30 years.
\end{abstract}

Keywords: Israel/Egypt, Yom Kippur war, Palestinians, PLO, Arab League, peace process

\section{Introduction}

On November 26-28, 1973, about one month after the cease-fire at the end of the Yom Kippur War (October 24th), the Arab League met in Algiers. During this summit conference, the Arab states, with the exception of the Kingdom of Jordan, decided that the national rights of the Palestinian people would be returned only in a way acceptable to the Palestine Liberation Organization (PLO) which was acting as its sole representative. Likewise, it was agreed that there would be no negotiations with Israel unless they were approved in advance by the PLO. Thus, for all practical purposes, the Arab states rejected the demand by King Hussein to recognize his rights in the West Bank and even encroached upon his right as the representative of "Jordanians of Palestinian origin" living in Trans-Jordan (close to sixty percent of the population). (Backer, 1984, pp. 102-103; Al-Nahar, December 4, 1973; Ahbar al-Yom, November 2, 1974). Why did the PLO attain the status as the sole representative of the Palestinian people immediately after the Yom Kippur War? Is there a connection between the general Arab recognition of the PLO and the Yom Kippur War? The purpose of this article is to examine the contribution of the PLO to the war effort of the Arab countries during the Yom Kippur War, the influence of the war upon the Palestinian problem and its contribution to the elevated position of the PLO.

\section{The Palestinian Contribution to the Arab Limited Victory}

On the face of it, what could the Palestine Liberation Organization have contributed to the war effort of the Arab countries during the Yom Kippur War? Historical research on the war, particularly on the part of Israelis, displays a tendency to minimize the role of the PLO as much as possible. Thus, for example, according 
to Middle East expert, Ya'acov Shimoni, "the terrorists-for whom it could have been their finest hour, their opportunity for daring guerilla campaigns against a wounded Israel, mired in war-engaged in a limited and routine launching of mortars and bazookas across the Lebanese border and did not make a real contribution to the war effort" (Shimoni, 1990, p. 343). In comparison with all of the Arab countries which sent forces and donated a considerable amount of money to the Egyptian-Syrian war effort, Palestinian efforts seem to have been relatively minimal. ${ }^{1}$

Nevertheless, the decision of the Sixth Summit in Algiers, as quoted in the Lebanese newspaper, Al-Nahar, included the following military commitments on the part of the Arab countries: "Providing every means of military and financial support for both the Egyptian and Syrian fronts in order to strengthen the campaign of liberation and steadfastness against the enormous supplies and the unlimited aid which the enemy is receiving". In addition, a decision was accepted to "support the Palestinian resistance by all means possible in order to ensure its active role in the campaign ..." (Al-Nahar, December 4, 1973). A close examination of these and other sections which appear in the decisions presents the Palestinians as one of the three belligerents in the October War. Therefore, the Palestinians "deserve" the solidarity of the Arab countries along with considerable financial and military support for their activities immediately after the Yom Kippur War.

According to General Mazin Izz al-Din, a former Palestinian diplomat who strives to elevate and promote the history of the Palestinian military units on the internet, the new arrangement and actions of the Palestinian guerillas between the wars distracted Israel from rebuilding its army after the Six Day War (Jiran Dier al-Asad Site, 2013). On January 27-30, 1973, the joint defense council of the Arab League with Marshal Ahmad Ismail from Egypt, presented the attack plan and according to General Izz al-Din, the Palestinians were present.

Dr. Abdallah Franji, a prominent figure in the PLO and a member of the Fatah movement who served on the Palestine National Council and as the PLO's ambassador in Germany from 1970-2004, and who currently serves as an adviser on foreign affairs to Chairman Mahmoud Abbas (Abu Mazen), in his book gives a lengthy description of the important activities of the Palestinians during the October War.

The PLO leadership was first informed of preparations for another Middle East war in May 1973. On September $12^{\text {th }}$, after a meeting of the Non-Aligned States in Cairo, Sadat assured Arafat that he would inform him of the precise date of the Arab attack. On September $30^{\text {th }}$ a message asking the PLO leadership to come to Cairo was transmitted via the Egyptian embassy in Beirut. However, Abu Lutf (Faruq al-Qaddumi) and Abu Iyad (Salah Khalaf) did not arrive in Cairo until October $4^{\text {th }}$. They were received by Sadat and told about the imminent attack. Instead of a code, a messenger was sent to Yasser Arafat, who received the news shortly before the outbreak of the war. All PLO units were immediately put on the alert. These units consisted of guerrillas with no training in conventional warfare. Their task was to open up a new front in the occupied areas. (Franji, 1983, p. 135)

Faruq al-Qaddumi describes this meeting in his memoirs which were documented in the television series Hakaya al-Thawra produced by the Al-Jazeera network in 2008.

On that day, Abu Iyad contacted me and told me that Sadat wanted to meet with us. We got organized and traveled in our old car.... we arrived at Burj al-Arab (the Presidential Palace); ahlan wa-sahlan and a hundred greetings. We were there and the truth is that he [Sadat] liked Abu Iyad very much. He told him...tomorrow is the time when the sparks will fly and we are crossing the canal and inshallah (God willing) after ten kilometers, we will stop and get organized. I will need you because when the fighting stops, you will finish the job. Send 300 or 400 fidāīyin [those who sacrifice themselves - Fatah warriors] and go to Abd al-Salam and begin the war of the fidāìñn against [the enemy] forces. I need

\footnotetext{
${ }^{1}$ Morocco sent 1,800-7,000 troops to assist the Syrians, Iraq, 6,000-18,000 soldiers and armored units, and Sudan, Algeria, Tunisia and Libya provided a considerable amount of aid to the leaders of Egypt and Syria.
} 
you more than all the men and the brothers. You know and I know who loves you and who does not. We said: all right... (Al-Jazeera, November 15, 2008)

In the same program of the series Hakaya al-Thawra, Mamduh Nufal, the military commander of the Democratic Front for the Liberation of Palestine (DFLP), mentions that after his meeting with Sadat, Abu Iyad and Abu Lutf went back to Arafat, although at first they did not believe that Sadat really intended to attack Israel. In fact, he had told them on several occasions that war would break out and then, retracted his statement. The only one who believed Sadat was Arafat. On the day after the meeting, Arafat immediately gave the orders to convene all of the commanders of military forces and to prepare for war against Israel (Al-Jazeera, November 15, 2008).

Abu Iyad's descriptions indicate that as early as March 1973, they knew of the approaching war and, the following four members of a Palestinian delegation, met with Sadat: Abu Iyad, Yasser Arafat, Yusuf an-Najar and Khalil al-Wazir (Abu Jihad). During this meeting, they received the mistaken impression that fighting would begin in May 1973. Sadat complained about Abu Iyad's statements regarding his problematic association with the Kremlin and with the USSR which did not supply him with strategic weapons which would enable him to win the war (Abu Iyad with Eric Rouleau, 1978, p. 121).

However, Mazin Izz al-Din reports that Chinese weapons started to arrive in Syria and were distributed to Palestinian forces as well (Jiran Dier al-Asad Site, 2013). In mid-August 1973, at another meeting with Sadat, Faruq al-Qaddumi and Abu Iyad already knew of Sadat's intention to go to war against Israel toward the end of 1973. Sadat mentioned that he had chosen a name for his military campaign ("The Spark") whose explicit aim was to extricate the Arab-Israel conflict from the deadlock which it had reached. Furthermore, Sadat stated that after the war the PLO would be able to participate in the Geneva Conference as the representative of the Palestinian people alongside Israel and other states. According to Abu Iyad, Sadat said in their meeting "So we'll all go to the peace conference together" (Abu Iyad with Eric Rouleau, 1978, pp. 122-123). Sadat's meeting with the Palestinian leaders was kept secret, even from the Syrians. Sadat designated Abd al-Salam Tawfiq, head of Egyptian Intelligence, to deal with the practical problems regarding the participation of PLO units. However Mazin Izz al-Din reports that Sadat informed Abu Ammar (Yasser Arafat) and his officers of an attack to take place in September not October (Jiran Dier al-Asad Site, 2013).

On September 9, 1973, Sadat invited Arafat, Faruq Qaddumi and Abu Iyad to an additional meeting, where he revealed his war plans in detail. In the presence of Arafat, they spoke about the peace conference which would take place after the war. It was not mentioned that Sadat was aware of the fact that a peace conference would take place after the war. It actually was held in Geneva in December 1973. Sadat also knew which countries would participate in the Conference and informed the PLO as follows: the United States; the USSR; Egypt, Syria, Israel, Jordan and the PLO. He definitely believed that the PLO should take part in the political process along with the Arab countries at any peace conference to be held after the war. Another meeting between Arafat and Sadat took place on September 12, immediately after the Conference of Non-Aligned States. There Sadat promised that he would update Arafat regarding any development in his preparations for war (Abu Iyad with Eric Rouleau, 1978, p. 122; Franji, 1983, p. 135). The Geneva Conference was behind the decision to attain the PLO status just after the war.

In light of this information, the PLO leaders had a period of about two months to prepare their forces, as they knew both the appointed time and the aims of the war. Abu Iyad recalls that among the PLO, there were 
those who were highly skeptical whether Sadat was serious. For example, when he received a message from the Egyptian embassy in Beirut on September 30, 1973, Abu Ahmed Al-Yamani, an active member of the Popular Front for the Liberation of Palestine (PFLP), notified fidāiỳn groups that he bet "entire sheep that Sadat won't make war." Abu Iyad agreed and won this bet (Abu Iyad with Eric Rouleau, 1978, p. 123). This was the same attitude of the Israeli Intelligence regarding Sadat. In their eyes, Sadat seemed to be incompetent and dumb (Shamir, 2013).

Muhammad Hasnin Heikal, editor of Al-Ahram who was close to Egyptian government circles, wrote that on October 1, 1973, several officers of the Palestinian resistance arrived with 120 men of various ranks in order to take part in the planned battle, along with Egypt (Heikal, 1975, p. 28; Cobban, 1984, p. 56). Only on Thursday, October 4 (Franji, 1983), did Abu Lutf arrived for a decisive meeting with Sadat, where the final details regarding Palestinian participation in the war were concluded. Abu Iyad further relates that when he arrived in Cairo, Egypt's Minister of Defense, Marshal Ahmed Ismail, waited for him and brought him to Sadat's office, while scolding him for his lateness and informing him that the war would break out in two days, exactly on Saturday, October 6, 1973 (Abu Iyad with Eric Rouleau, 1978, p. 123).

Zuhair Mohsen, a Palestinian commander of the pro-Syrian group, Al-Sa'iqa, and a member of the Syrian Baath' party, also had received information about the October war and was preparing for it (Amos, 1980, pp. 104-105). The above constitute part of the evidence attesting to the fact that the PLO and the organizations under its aegis definitely knew about the imminent war and were prepared for it as best as they could be (Amos, 1980, p. 213).

In the message that Arafat received in Beirut updating him regarding the beginning of the war and the task of the Palestinians, the Egyptians knew that Palestinian forces were not prepared for battle against a regular army. Their roles were to commit acts of terror inside Israel, the West Bank and the Gaza Strip. Sadat emphasized to Abu Lutf that fidāiȳin activity was important because it would impair the long supply lines from Israel proper to the Egyptian front. Sadat declared: "My armies will push on to the Mitla and Giddi passes which control the Sinai. Then I'll leave it to the fidāìyin to carry on the guerrilla war!" (Abu Iyad with Eric Rouleau, 1978, p. 124).

Franji argues that the Israelis counted over 200 attacks by the PLO guerillas throughout the war. Likewise, according to Franji, Israel's ambassador to the United States published that the Palestinians attacked over 43 kibbutzim during the war. According to Franji, in addition to guerilla warfare against Israel, the fidāiyin fought alongside the Egyptians, Syrians and Iraqis (Franji, 1983). These statistics appeared in several newspapers and in interviews with Arafat conducted during the war and after its conclusion. Generally speaking, it is noted that the Palestinians conducted 200 attacks including 42 attacks against settlements, lines of vehicles, airfields, fuel storage depots, points of military deployment and radar installations. Most of the settlements attacked were located in the area of Qiryat Shmona. The Palestinians also boasted of successfully disrupting Israel's supply lines in area between Khan Yunis and Beersheba. Arafat bragged that the Egyptians requested only fifty attacks, but fidāìyin forces under his leadership conducted 150 additional strikes (Daily Star, January 6, 1974; Amos, 1980, p. 213). In addition to fidāiȳn actions in the Sinai, the Egyptians also activated a small group of Palestinian and Bedouin Arab guerillas from the Sinai under Egyptian officers. It took part in gathering intelligence and guerilla warfare against the Israeli enemy. This group had been activated by the Egyptians during the War of Attrition (1968-1970) as well (Amos, 1980, pp. 110-111). 
Abu Iyad has brought additional information regarding Palestinian activities during the Yom Kippur War, and explained as follows:

A number of Palestine Liberation Army (hereinafter: PLA) unites had been helicoptered behind Israeli lines on the first day of the fighting and seized the hills in Kuneitra on the Golan. From south Lebanon, fidāiȳin commandos crossed over into Israel to attack the rear lines of the Jewish army in Upper Galilee. Others shelled a number of kibbutzim beyond the Lebanese border. As of October 6, some 70,000 Palestinian workers employed by Israeli enterprises went on strike in the West Bank and Gaza. In all, we launched more than 100 operations during the first week of the war, according to no less a source than Golda Meir herself. (Abu Iyad with Eric Rouleau, 1978, p. 126)

Abu Iyad also mentions that forces of the Palestine Liberation Army and units of the Fatah fought alongside Kuwaiti troops in Deversoir near the Great Bitter Lakes (Timsah) in the estuary where Gen. Ariel Sharon broke through on the eastern shore of the Suez Canal and surrounded the Egyptian Third Army, on October 14. "Our men fought heroically; many died" (Abu Iyad with Eric Rouleau, 1978, p. 127).

The number of Palestinian forces which participated in battles on the Golan Heights, in southern Lebanon and the Sinai is quite impressive. According to Palestinian accounts, there were about 26,000 fidāìyin conscripts under a unified command who fought on the three fronts. And, at least 500, took part in active fighting inside Israel (Daily Star, October 11, 1973; Amos, 1980, p. 213). According to another source, Palestinian forces conquered some of the mountain peaks south of Mt. Hermon near Abu Raus (As-Sayyad, October 10, 1973; Amos, 1980, p. 213). In addition, the PLA and not only guerilla organizations took part in battles. Some 5,000 PLA soldiers, the Yarmukh and Ein Jalut brigades, were positioned in Jordan during the war under the command of the Jordanian army in case of an Israeli attack. The Hittin Brigade of the PLA participated in fighting with Syrian soldiers in the Golan Heights. The Battle of Tel el-Faris is described as a heroic battle in which the forces of the PLA fought alongside the Syrian army. Forces of the Yarmukh Brigade under Syrian command entered southern Lebanon and were active from there. Forces of the Ein Jalut Brigade placed under Egyptian command were positioned with brigades from the armies of Kuwait and Algeria near the Suez Canal in the Sinai. This was where General Ariel Sharon broke through and crossed the canal on October 15, in the move that changed the course of the war (Jayish al-Tahrir al-Falistini (PLA), website, 2013; The Times, 1973). According to Arafat in an interview that was published in al-Ahram, the Palestinian loses were 870 deceased and missing (Asher, 1974, p. 56).

Why was the voice of the Palestinians not heard throughout the war? Why were their activities not given prominence? Abu Iyad explained as follows: "The October War unfolded without much talk of the Palestinians. The military communiqués broadcast from Cairo and Damascus trumpeted the Egyptian and Syrian victories, but more often than not omitted any reference to our feats of arms or even our presence. In fact, we were active on all fronts" (Abu Iyad with Eric Rouleau, 1978, p. 126). According to Mazin Izz al-Din, Ein Jalut forces fought at the canal. Many Palestinian forces including Qadisiya and al-Sa'aiqa, fought in the Golan Hieghts including the battle of Tel Faris and there were foot infiltrations and shooting of mortars and cannons from the Southern Lebanese front. All this was coordinated with Egyptian and Syrian officers (Jiran Dier al-Asad Site, 2013). It is noteworthy that Anwar Sadat's memoirs do not mention the Palestinian contribution, as it was, to his "victory" in the Yom Kippur War (Sadat, 1978). Therefore, it probably was a very minimal contribution or was swallowed up in the performance of the Egyptian and Syrian armies.

Attempts to persuade King Hussein to open a third front against Israel with the help of fidāiy in who would infiltrate into the West Bank and commit terrorist attacks against Israel failed because of his vehement 
objections. Hussein even refused an explicit written request from Sadat to enable the infiltration of terrorists affiliated with various groups of the PLO, from Jordan into Israel or to facilitate the movement of Iraqi or Syrian brigades through Jordanian territory. King Hussein deigned to send one armored brigade to Syria on October 13, only after heavy pressure from the Arab countries (Abu Iyad with Eric Rouleau, 1978). Nearly 1,000 members of the different PLO groups were planning to enter Jordan and, from there, to infiltrate into Israel via the Jordan Valley in order to perpetrate acts of terror in Israel. According to Heikal, when the Palestinians discussed Hussein's refusal with Sadat on October 11, he expressed doubts as to whether he could change King Hussein's decision. A week later, when it was clear that Israel had gained the upper hand, Sadat tried to reach Hussein on the telephone many times in order to convince Hussein to activate the 1,000 guerillas in the Jordan Valley thereby opening a third front. His efforts were in vain. King Hussein ignored Sadat's phone calls several times. After their conversation finally took place, the King took his time in replying to Sadat and made his request a hypothetical issue (Heikal, 1975, p. 56). Nevertheless, a small Palestinian force managed to cross the Jordanian border and attack targets near Jerusalem (As-Sayyad, October 10, 1973; Amos, 1980, p. 213). Hussein's delays and his refusal of Sadat's explicit request for help throughout the war also would find expression at the conferences in Algiers and Rabat, as will be seen below.

Abu Lutf and Abu Iyad remained in Cairo throughout the war and helped coordinate between Palestinian and Egyptian and Syrian troops. Abu Lutf and Abu Iyad met with President Sadat at the al-Tahara Palace as early as October 6 at seven P.M. on the first day of the war. Sadat was excited about his initial success. After a while, however, Abu Iyad and Abu Lutf understood that Sadat had limited his war aims to conquering a narrow strip of several kilometers east of the Bar-Lev line and exerting political pressure upon Western countries through the use of the oil embargo (Abu Iyad with Eric Rouleau, 1978, pp. 122-125; Ben-Rafael, 1987, pp. 77-78).

Perhaps Palestinian activity may be regarded as inflicting slight damage against the home front of the enemy. Arafat and other Palestinian spokesmen, however, argue that not only were the Egyptian and Syrian fronts important, but the Palestinian front played a significant role as well. Arafat confirms this view by saying that the PLO opened up a third front after the Egyptian and Syrian fronts (Franji, 1983, p. 135).

Abu Iyad presents similar arguments regarding the period between the Six Day War and the Yom Kippur War, as follows:

The Palestinian movement today [1978] does not have the means it enjoyed in June 1967. At that time, the Arab disaster did not prevent us from pursuing and intensifying our guerilla activities, thus showing the Zionists that the war wasn't over, despite their brilliant victory. At the same time, we raised the morale of the Arab masses, projecting a ray of hope in the darkness of defeat and occupation. We had strongholds from which we could launch our raids against Israel. The prestige we enjoyed enabled us to exert an influence, sometimes decisive, on the policy of various capitals.... Without exaggerating, I can say that we contributed to the psychological preparation and triggering of the October 1973 war [Author emphasis] just as we hadn't been foreign to the June 1967 conflict. (Abu Iyad with Eric Rouleau, 1978, p. 220)

There is something in Abu Iyad claims. Israeli Intelligence officers admitted after the Yom Kippur war that they were concentrating on Palestinians terrorist organizations before the war with Egypt and Syria. In April 1973, the IDF made Operation "Aviv Ne'urim” against Palestinians headquarters in Beirut. In July 23, 1973 there was the Lillehammer affair. Israeli agents mistook their target for Ali Hassan Salameh, the chief of operations for Black September. Six of the Mossad team of fifteen were captured and convicted of complicity in the killing by the Norwegian justice system, in a major blow to the intelligence agency's reputation. In 
August 1973, Israel tried to intercept the head of PFLP, George Habash's airplane (Lapid, 2013; Barkai, 2014, pp. 22-23). ${ }^{2}$

From the outset, Sadat insisted upon including the Palestinians in the war and gaining their support and guarantees. Abu Iyad relates that in retrospect, when he reviews the many hours which they spent with Sadat during the war, it seems that Sadat's reasons were as follows: "I think he was trying to make sure of Palestinian support either if he lost the war-which would have been a catastrophe for his political future - or if he won. In which case, he hoped to win our confidence so as to integrate us into the peace process he planned to initiate" (Abu Iyad with Eric Rouleau, 1978, p. 126).

Sadat wanted to include the Palestinians at the Geneva Conference which officially opened on December 21, 1973. Despite Sadat's wishes, the Palestinians were not included in the conference because of heavy American pressure which led to their rejection. Palestinian leaders were not prepared to understand the importance of the United States in negotiations with Israel (Cobban, 1984, pp. 59-60).

The lesson which the Palestinians learned from the Yom Kippur War was that the qualitative gap between Israel and the Arab countries was reduced significantly. The war was proof of this. Thus, the Arabs changed the balance of power in their favor. Syria retook the Golan Heights for a short time and Egypt, a considerable part of the Sinai and the Suez Canal (despite the Israeli victory at the end of the war) (Al-Rai, April 2, 2013). According to Arafat, if the Arabs would persist in their determination and initiate wars such as the October War, eventually they would prevail. Such statements appear in an interview with Arafat in the newspaper, Al-Hawadith, in 1979, where he relates to the Yom Kippur War and to Sadat's peace initiative (Al-Hawadith, June 5, 1979).

Franji explicitly argues that the participation of the Palestinians alongside the Arab countries in the fourth Arab-Israeli war, while Jordan refrained from doing so, had important political implications for Jordan. They were evident at the Fifth Summit Conference of the Arab League held in November 1973. Yasser Arafat attended this conference in the capacity of a head of an independent state. For the first time, the PLO was recognized as the organization representing the entire Palestinian people, including Palestinians who lived in Jordan. King Hussein opposed the upgrading of Arafat's status, but was silenced by Algerian President Houari Boumedienne. The Arab countries recognized the PLO as the sole legitimate representative of the Palestinian people. Henceforth, any negotiations or solution of the Palestinian issue would commit the Arab countries to include the PLO and to obtain its consent. According to Franji, this political status was achieved mainly because of active Palestinian participation with the Egyptians and Syrians during the war (Franji, 1983, p. 138).

The Palestinians definitely could expect a political reward as a result of their participation in the war. This reward would find its expression in any political process dealing with a solution to the conflict. The PLO and the fidāìyin organizations had come a long way since 1967. They had expanded their ranks considerably. After the Battle of Karameh (1968), they had achieved a broad consensus and gained popular support among Palestinians. Despite the fact that they had been crushed by King Hussein's regime in Jordan (1970-1971), they had achieved broad inter-Arab recognition and even managed to reestablish themselves in Lebanon. In light of the above, the leaders of the PLO and especially the leaders of Fatah believed that the time had come for them to receive their political reward and to overcome Jordanian opposition to their upgraded status in the Arab and international arena. Mazin Izz al-Din mentions the great political achievements for the PLO after the war

\footnotetext{
${ }^{2}$ Barkai interview with Major-General, Eli Zeira, head of IDF Intelligence in 1973.
} 
including recognition as sole representative of the Palestinian People in Rabat October 1974 (Jiran Dier al-Asad Site, 2013).

\section{Rejecting Jordan}

During the Six Day War, King Hussein lost the West Bank. Until the First Armed Uprising (intifada) (1987-1993), he tried to restore the West Bank to the Kingdom of Jordan. The loss of the West Bank inflicted considerable harm to the Jordanian economy. Forty-percent of the gross national product of Jordan came from the West Bank. Until June 1967, 65\% of the fruits and vegetables and 80\% of the olives came from the West Bank. In addition to economic damage, the King suffered the loss of prestige among Arabs as he had been the custodian of the holy places in Jerusalem. Shortly after the Six Day War, King Hussein started diplomatic efforts in order to reach an agreement with Israel, with Western mediation, with the purpose of restoring the West Bank to Jordan. These diplomatic approaches were not successful despite his moderate stance and his reputation (Bailey, 1981).

At the same time, Hussein had to challenge the arguments of the PLO that it, and not Jordan, represented the Palestinians wherever they lived, including the Hashemite Kingdom. The struggle for hegemony among the Palestinians in Jordan and on the West Bank took on different forms, including violent confrontations between the Jordanian army and Palestinian fidāì̄in groups in "Black" September 1970 and in July 1971. On March 15, 1972, Hussein presented his plan of a united Arab kingdom. According to this plan, should Israel restore the West Bank to Hussein's rule within the framework of mediation and diplomatic pressure, a Jordanian kingdom would be established. It would consist of two federative districts: Palestine and Trans-Jordan. "The District of Palestine would include the West Bank and all other Palestinian territories which would be liberated and whose residents wish to join it". Thus, negotiations would begin with Jordan regarding the Gaza Strip and exchanges of territory as well. The capital of the District of Palestine would be Jerusalem and of the District of Jordan, Amman, which also would be the capital of the Kingdom (Radio Amman on March 15, 1972). The strong political position of Hussein and the support for his plan in the West Bank were evident in municipal elections which were held under Israel's supervision in 1972 and reflected his belief that his program could be accomplished and that other Arab countries eventually would come to terms with him ( Bailey, 1981).

The leaders of the PLO were hostile toward Hussein's political program which offered a possible solution which claimed to represent the residents of the West Bank. They viewed King Hussein as an enemy of the Palestinian people, who tried to harm the achievements of the Palestinian revolution and retake the West Bank for himself. The purpose of the Ten-Point Plan presented by the PLO in 1974, after the Yom Kippur War, was first and foremost a challenge to the Jordanian political program (Abu Iyad with Eric Rouleau, 1978, pp. 139-140).

Article Five in the Ten-Point Plan, actually was conceived as opposition to King Hussein, his government and his plan. It reads as follows: "[The PLO will] struggle along with Jordanian national forces to establish a Jordanian-Palestinian national front whose aim will be to set up in Jordan a democratic national authority in close contact with the Palestinian entity that is established through the struggle" (Mahler and Mahler, 2010, p. 142) [Author emphasis]. The Ten-Point Plan made the Palestinian position more flexible because, for the first time, the PLO officially agreed to establish a Palestinian national authority over any liberated territory alongside the State of Israel. Although the PLO abandoned neither the armed struggle nor its vision of liberating all of Palestine from the (Jordan) River to the (Mediterranean) Sea, the Twelfth Palestinian National 
Council, which ratified the Plan (June 1974), was aware of the possibility of an interim stage during which there would be two states - Palestine and Israel — existing alongside each other (Cobban, 1984, pp. 60-61; Amos, 1980, pp. 271-272). This political program enabled the PLO to enter into a political process and to acquire an understanding for its workings on the part of European countries as well. It helped the PLO to gain observer status at the United Nations and international recognition (Amos, 1980, p. 272).

The basic argument of King Hussein was that as the sovereign ruler of Jordan, he had the right to represent "Jordanians of Palestinian origin" living within the territory of his kingdom. Similarly, as the West Bank was part of the Kingdom of Jordan prior to the Six Day War and its residents held Jordanian citizenship which was not rescinded in the wake of Israel's takeover, he was responsible for representing them before Israel and at any international conference. Therefore, King Hussein abstained from supporting the decision of the Arab countries which designated the PLO as the sole legitimate representative of the Palestinian people, at the Algiers Conference in November 1973. The King's measures toward the PLO regarding Palestinian representation were merely stopgaps in the political campaign which Jordan kept losing. From the outset, Hussein had opposed the establishment of the PLO at the Summit Conference in January 1964, but was forced to agree under pressure from Gamel Abd al-Nasser. As long as he controlled the West Bank, Hussein could argue that he represented all Jordanian citizens of Palestinian origin who lived in his kingdom. After the 1967 War, however, and, especially after the violent confrontations with Palestinian fidāìȳn groups (1970-1971) which had great prestige among Palestinians, all his efforts to secure legitimization for his regime on the part of Palestinian groups met with failure. Hussein's 1972 political program which called for establishing an autonomous Palestinian district which would restore the name of "Palestine" to the political arena after his grandfather King Abdallah had wiped it out, were too little and too late. While Hussein managed to delay the decision, at the end of the day and under considerable political pressure, particularly from Egyptian President Sadat, he was forced to accept the Arab consensus at the Rabat Conference and recognize the PLO as the sole legitimate representative of the Palestinian people (Shemesh, 2004, pp. 696-709).

For all intents and purposes, both King Hussein and the Palestinian leadership tried to advance their respective political programs by obtaining the support of the Arab countries, particularly Egypt. Abu Iyad describes how U.S. Secretary of State Henry Kissinger managed to maneuver both Hussein and Sadat against the Palestinian leaders. Kissinger convinced Hussein that the West Bank would be restored to him so that he could fulfill his plan of federation. Therefore, as opposed to all the other heads of Arab states, he abstained from approving the decision accepted at the Algiers Conference after the October War of 1973. The decision was kept secret only because of Jordanian opposition. On December 1, 1973, King Hussein publicly declared that Jordan must obtain Israel's withdrawal from all the captured territories. Afterward, a plebiscite would be held which would enable the Palestinian people to express its wishes regarding its future. Thus, according to Abu Iyad, Hussein had understood that he could demand the right to represent the Palestinians at the Geneva Conference. As far as they were concerned, the Palestinians never intended to make that possible (Abu Iyad with Eric Rouleau, 1978, p. 143). As long as there was no unified Arab decision explicitly recognizing the right of the PLO to represent all Palestinians, the PLO was absent from the political process which began after the Yom Kippur War. Kissinger did not conceal his preference for Hussein and, on February 8, 1974, at a meeting with leaders of the American Jewish community, he warned that if Israel did not make several concessions toward Hussein and compromise with him, the position of Arafat would get stronger and he would attain international legitimization. Kissinger even asserted that if he were an adviser to the government of Israel, he 
would tell them: "For God's sake, close something with King Hussein while he is still one of the players" (Kissinger, 1982, p. 976). His warning came true some seven and a half months later at the Rabat Conference.

The Algiers decision of November 1973 did not constitute the final chapter in the struggle between Jordan and the Palestinians over Palestinian representation. The Palestinians knew that the decision had remained a secret and that as long as King Hussein persisted in opposing it, their position as the sole Palestinian representative of the Palestinian people could not be taken for granted. Abu Iyad describes the period between the Algiers and the Rabat Conferences as follows: "None of the other Arab heads of state reacted to his statement. In fact, some of them clearly regretted their vote in our favor at the Algiers summit. Sadat showed his true colors some months later. At the end of King Hussein's visit to Alexandria on July 18, 1974, Sadat subscribed to the joint communiqué which recognized the King's right to speak in the name of all the Palestinians living in the Hashemite kingdom (more than 1,000,000) ..." (Abu Iyad with Eric Rouleau, 1978, p. 144). Abu Iyad continues as follows: "The danger was taking shape when a new Arab summit was convened for October 26 in Rabat. The agenda naturally included the problem of Palestinian representation. Unknown to the Fatah's leadership, a group of young militants decided to kill King Hussein if he succeeded in convincing his fellow rulers to reverse the position they had adopted toward the PLO during the Algiers summit of November 1973. Whatever the cost, the PLO was to remain the 'sole legitimate representative of the Palestinian people"” (Abu Iyad with Eric Rouleau, 1978).

On October 26, 1974, the Rabat Conference took place. A group of activists organized by the PLO planned to assassinate King Hussein during his stay at the Rabat Conference, thereby preventing him from again bringing about the failure of the decision of the Arab countries to recognize the PLO as the sole political representative of the Palestinian people. After the Palestinian plot was revealed and it was rumored that the intention was to wipe out the entire leadership of the Arab countries, all of the heads of Arab states voted for the historic decision. That is Abu Iyad's somewhat simplistic explanation for the change in Hussein's approach to the issue of Palestinian representation (Abu Iyad with Eric Rouleau, 1978).

However, after analyzing the statements of Abu Iyad and of other Palestinian leaders like Khalid al-Hassan, it appears that the fact that Hussein did not participate in the Syrian-Egyptian war effort during the Yom Kippur War was the real catalyst which led the Arab countries to support the PLO as the representative of the Palestinian people. This recognition led to the PLO political program whose purpose was the establishment of a small Palestinian mini-state on the territories of the West Bank and the Gaza Strip (Cobban, 1984, p. 61). Jordan could never initiate a political program for the West Bank again without cooperating and coordinating with the PLO.

The articles accepted and approved at the Rabat Conference were clear and unequivocal. Article Two reads as follows: "The Conference again confirms the right of the Palestinian people to establish an independent national authority under the leadership of the PLO as the sole and legitimate representation of the Palestinian people in all of the liberated Palestinian territory. The Arab countries are committed to support this authority from the moment it is established, in all spheres and in all ranks" (Arnon-Ohana and Yodfat, 1985, p. 270). Article Four dealt with the arrangement of relations between Jordan, Syria, Egypt and the PLO; the organization of these relations as a result of the decisions; and the ways of carrying out those decisions (Arnon-Ohana and Yodfat, 1985). In the secret protocol of the conference, there were similar statements rejecting any other political arrangement. The decisions were accepted after statements by King Hussein, Yasser Arafat and the other Arab rulers. It was noted that the basis for accepting these decisions were the 
victories achieved by the Palestinian struggle against the Zionist enemy (As-Safir, November 30, 1977). The military assistance of the Palestinians during the Yom Kippur War was to be worthwhile.

\section{Summary and Conclusions}

Arab recognition of the PLO as the sole representative of the Palestinian people and the subordination of their interests in anything relating to Israel to the PLO derived first and foremost from the results of the Yom Kippur War. Conventional wisdom maintains that the Yom Kippur War was a Syrian/Egyptian war against Israel. According to Palestinian sources, however, the Palestinians also played an active part in the war, alongside the Arab countries. The war was considered by the Arabs as a victory accomplished through the use of deception by surprise and by the choice of Yom Kippur as the date of the attack. As a result, the Palestinians had a right "to profit" from the Arab "victory" in some way.

It is difficult to evaluate the military affect of the Palestinians during the war because of the absence of adequate sources and of support for their claims. Nevertheless, one cannot dismiss their contribution out of hand. Even if their contribution was minor and associated with morale, one must mention their definite stance alongside the Arab states of Egypt and Syria and their partnership with the two countries both at the outbreak of hostilities and in their results. Gratitude to the PLO was expressed by sweeping political recognition, with the exception of Jordan, immediately after the war at the Algiers Conference in November 1973.

It was the Egyptian President Anwar Sadat who led the Arab countries with a consistent line of support for the PLO as the representative of the Palestinians. Sadat definitely saw the PLO as a possible negotiating partner with Israel and the United States and as a partner in the peace process which began at the Geneva Conference after the war. For this reason, at the conference of the heads of Arab states, held immediately after the war, in November 1973, the historic decision was made to recognize the PLO as the sole legitimate representative of the entire Palestinian people, despite Jordanian objections. The PLO did not participate in the Geneva Conference at the end of the year because of the opposition of the United States and of Israel and the fact that it did not have a realistic political program which would enable its participation in the political process. The PLO paved the way for its participation in the political process and international recognition as the legitimate representative of the Palestinian people about a year after the war when it presented the Ten Point Plan in 1974 which was adopted by the Palestine National Council. This recognition found expression in Arafat's speech at the United Nations Headquarters in Geneva on November 13, 1974. The Ten Point Plan suited Egyptian policy according to Sadat and his successors. From PLO point, it advocated a small Palestinian mini-state in the territories of the West Bank and the Gaza Strip as an intermediate stage before freeing all Palestine (Abu Iyad with Eric Rouleau, 1978; Shemesh, 2004). It took years after the Yom Kippur War for the PLO to understand the importance of the U.S. for any diplomatic settlement with Israel and the measures taken by Sadat.

Support for the Palestinians was conspicuous in Egypt and in Syria in contrast to the lack of support, or even the help to Israel by Jordan. Jordan opposed the October War and even warned Israel before it. Despite the fact that the war lasted for several weeks (from October 6 to 24, 1974), the Jordanians did not open another front against Israel, thereby possibly preventing a more meaningful feeling of an Arab victory. From the establishment of the PLO in 1964, the question of representation had been the focus of a political conflict between Jordan and the PLO regarding the Palestinians in Trans-Jordan and on the West Bank. At the end of the day, the outcome of the struggle over the right of representation and the preference of the Palestinians in Jordan and the West Bank was determined only after the Yom Kippur War. The Arab decision to recognize the 
PLO as the legitimate representative of the Palestinian people and the national liberation movement of the Palestinians won the definitive support of the Soviet Union which regarded the Palestinian cause as a means of preserving its influence in the Middle East (Amos, 1980, pp. 126-128). ${ }^{3}$ For those reasons, all of the Arab countries, especially Egypt, convened the Algiers Conference in November 1973 and ignoring the status of Pro-Western Jordan, they decided to grant recognition to the PLO. All of the efforts of King Hussein to change the decision were to no avail. At the Rabat Conference in 1974, even he was forced to accept the Arab consensus.

In light of those three major reasons: the Palestinian military contribution to the Arab war effort, Jordan's non-participation in the Yom Kippur War and the Egyptian attempt to include the PLO as the representative of the Palestinian people as part of a regional settlement within the framework of the Geneva Conference in December 1973, gave the PLO the recognition. The PLO became the sole legitimate representative of the Palestinian people. Eventually even Jordan was compelled to do so at the Rabat Conference in October 1974. Diplomacy and war have a lot in common with the theatre. In order to play a certain role and not break character, one must give a credible and believable show. In order for the PLO to receive its diplomatic legitimacy, it was compelled to contribute an active role on the battle field. Psychologically, in order to convince Sadat and for the purpose of their self esteem, the PLO had to appear as a Palestinian military force which fights for Palestine and does not only depend on the Arab states. The rewards were diplomatic and the PLO started his way for diplomatic compromise till the Oslo accords in the 1990s.

In the 1970s and the 1980s, it was clear in the worldview and Israel, that the PLO with Fatah leadership was the sole legitimate representative of the Palestinian people. In the last decades, because of the competition and separation between the Hamas and the PLO, it is not clear. These days we need another clear decision who is the sole legitimate representative of the Palestinian people - Fatah (PLO) vs. Hamas, Mahmoud Abbas (Abu Mazen) or Ismail Haniyeh. Only after Arab and Islamic common decision will be made, like it was in the 1970s, can peace come to the Holy Land.

\section{References}

Abu Iyad with Rouleau, Eric. (1978). My home my land, a narrative of the Palestinian struggle. New York: Times Books. Ahbar al-Yom. Cairo. (1974, November 2).

Amos, J. W. (1980). Palestinian resistance: Organization of a Nationalist Movement. New York: Pergamon Policy Studies.

Arnon-Ohana, Yuval and Yodfat, Aryeh. (1985). Ashaf: Dyokano shel Irgun (The PLO, Organization's profile). Tel-Aviv: Ma'ariv.

Asher, Ya'akov. (1974). Irguni Ha-Fedayeen be-Milhemet Yom Hakippurim ve-leahrieh. In Wintroub, Yocheved, Irguni Hamhablim. Tel-Aviv: Israel Defense Minister, Chief Army Education Officer.

Backer, J. (1984). The PLO: The rise and fall of the Palestine Liberation Organization. London: Pitman Press.

Bailey, Y. (1981). The Palestinians and Jordan between the Six-Day War and the Yom Kippur War. In E. Gilboa and M. Naor (Eds.), Ha-Sichsuch ha-Aravi-Iishraeli: Gormim, Imutim ve-Sikuyim (The Arab-Israel Conflict: Causes, Confrontations and Opportunities). Tel Aviv: Israel Ministry of Defense, pp. 174-195.

Barkai, A. (2014). Mshak Kanfi HaTaout [An Error's Flap of Wings]. Herzliya, Intelligence Heritage Center, pp. 22-23.

Ben-Rafael, E. (1987). Israel-Palestine: A guerilla conflict in international politics. New York: Greenwood Press.

Cobban, H. (1984). The Palestinian Liberation Organization: People, power and politics. Cambridge: Cambridge University Press. Daily Star. Beirut. (1973, October 11), (1974, January 6).

\footnotetext{
3 The position of the Soviet Union and its support for the PLO formed an integral part of Soviet policy and decisively influenced the policies of socialist Arab countries, such as Algeria, Syria, Libya, Iraq and Egypt before the latter changed its direction toward the Americans.
} 
Franji, Abdallah. (1983). The PLO and Palestine. London: Zed Books.

Al-Hawadith, Kuwait. (1979, June 5).

Heikal, Muhammad. (1975). The Road to Ramadan. New York: New York Times Books.

Al-Jazeera. (2008, November 15). "Hakaya al-Thawra: Al-Bandakiya wa-Ghsan al-Zeitoun." Available at, http://www.palestineremembered.com/GeoPoints/Palestinian_History_For_Beginners_5375/Article_11907.html

Jayish al-Tahrir al-Falistini (PLA). (2013, June 9). Al-Jayish al-Arabi. Available at, http://www.arabic-military.com/t74451-topic Jiran Dier al-Asad Site. (2013, November 15). Al-Quwat al-Falestiniya fi Harb October 1973: As-Shahid Abu Ammar wa-Qiyadat Fatah hum al-Wahideen alladin Ablaghhum as-Sadat bimo'aad al-Maaraka allati satawahadha Misr. Retrieved September 21, 2015, from, http://www.geran.co.il/news-3-9116.html

Kissinger, Henry. (1982). Years of upheaval. Boston: Little Brown and Co., p. 976.

Lapid, Efraim. (2013). Ama'n Nichshal Bemshimato Haikarit Kolel Maarack Ha-Isouf. [the Army Intelligence failed in his Main Mission including the Collection Alignment]. In: Meltser, Efi (Ed.), HaModia'ain Bemilhemet Yom Kippur, 1973, 40 Shana Ahri. Herzliya: Intelligence Heritage Center. pp. 46-49.

Mahler, G. S., \& Mahler, A. R. W. (2010). The Arab Israeli conflict, an introduction and documentary reader. Abingdon, Routledge.

An-Nahar. Beirut. (1973, December 4).

Al-Rai, Gaza. (2013, April 2). Al-Ahtilal: Al-Jaish al-Masri Dalalna fi Harb. Retrieved September 21, 2015, from, http://alray.ps/ar/index.php?act=post\&id=104219

Sadat, Anwar. (1978). Sipur Hayai. The story of my life. Jerusalem: Idanim (Hebrew translation).

As-Safir, Beirut. (1977, November 30).

As-Sayyad. Beirut. (1973, October 10).

Shamir, S. (2013). Matsava shel Misraim Arev Hatsliha Egyptian Situation before the Canal Crossing. In Meltser, Efi (Ed.), HaModia'ain Bemilhemet Yom Kippur, 1973, 40 Shana Ahri. Herzliya: Intelligence Heritage Center. pp. 20-29.

Shemesh, M. (2004). Mi-ha-Nakba la-Naksa: Ha-Sichsuch ha-Iisraeli-Aravi ve-ha-Ba'ayah ha-Leumit ha-Falastinit, 1957-1967: Darko shel Nasser le-Milhemet Sheshet ha-Yamim. [From the Nakba to the Naksa: The Israel-Arab Conflict and the Palestinian National Problem, 1957-1967: Nasser's Road to the Six Day War]. Jerusalem: Ben Gurion Institute and Ben Gurion University.

Shimoni, Ya'acov. (1990). Medinot arav: pirkei historia medinit. The Arab countries: Chapters in political history. Tel Aviv: Am Oved.

The Times. London. (1973, October 28). 